\title{
23. MAGMATIC SULFIDES IN BASALT GLASS FROM DSDP HOLE 319A AND SITE 320, NAZCA PLATE
}

\author{
E.A. Mathez, Department of Geological Sciences, University of Washington, Seattle, Washington \\ and \\ R.S. Yeats, Department of Geology, Ohio University, Athens, Ohio
}

\section{INTRODUCTION}

Basalts erupted in the abyssal environment invariably have higher sulfur concertrations than their subaerial counterparts because the latter are extruded under less pressure and are therefore more degassed (Moore and Fabbi, 1971). From recent work on the solubility of sulfur in mafic magmas (Haughton et al., 1974; Katsura and Nagashima, 1974), it appears that, although solubility is complexly related to a number of variables, chemical and physical conditions attendant on basaltic vulcanism on the ocean floor are such that these magmas should be saturated or nearly saturated in sulfur. The works of Moore and Calk (1971) and Anderson (1974) suggest that magmatic sulfides in oceanic basalts may be more ubiquitous than commonly thought. We find that basalt glasses from Leg 34 contain sulfides occurring as globules (spherical masses entirely within glass or crystals) and as spherules lining vesicle walls. Further, petrographic relations in these rocks suggest that the sulfides had exsolved from the silicate melt prior to eruption.

We describe sulfides from Sample 320-3-1, 100-106 $\mathrm{cm}$, interpreted as the outer glassy rind of a pillow margin, and from loose fragments recovered from basalt in Hole 319A. Core recovery in Hole 319A was fragmentary and consisted primarily of massive pieces of finegrained basalt, possibly the interiors of pillows. Glassy selvages of these pillows were rarely retrieved in place, but rather they were found as loose gravel in the bottom of the hole, recovered above the center bit. Our analyses are of four fragments of this gravel, and because they are similar petrographically and chemically, we treat them together. In addition to a description based on petrography and scanning electron microscopy, we present microprobe data on the compositions of sulfide globules and spherules, of the glasses, and of microphenocrysts of plagioclase and olivine.

\section{MICROPROBE PROCEDURES}

All microprobe analyses utilized mineral standards having compositions similar to unknowns, together with the EMPADR VII reduction program (Rucklidge and Gasparrini, 1969). Glass analyses were made with a 30$\mu \mathrm{m}$-diameter beam at $15 \mathrm{kv}$ acceleration potential and 80-100 namps sample current. The combination of large beam diameter and moderate sample current effectively eliminated alkali loss. Counting times were terminated on fixed beam current, and their durations $(\sim 10-30 \mathrm{sec})$ depended on the concentrations of elements being analyzed. Our experience is that good mineral standards yield valid glass analyses when formal reduction procedures are followed. These standards (elements for which they were used) were bytownite $(\mathrm{Si}, \mathrm{Al})$, synthetic Ti diopside (Ti), olivine ( $\mathrm{Fe}, \mathrm{Mg})$, albite $(\mathrm{Na})$, orthoclase $(\mathrm{K})$, synthetic chalcopyrite $(\mathrm{S})$, apatite $(\mathrm{P})$, and garnet $(\mathrm{Mn}) . \mathrm{Ca}$ was calculated by a curve fit to other glass standards. By reproducing analyses of glass standards run with unknowns, we estimate accuracies relative to absolute element concentrations of $<1.5 \%$ for $\mathrm{Si}, \mathrm{Ti}, \mathrm{Al}$, and $\mathrm{Na}$; and $1.5 \%-2.5 \%$ for $\mathrm{Ca}, \mathrm{Fe}$, and $\mathrm{Mg}$.

\section{PETROGRAPHY AND MINERALOGY}

The Leg 34 samples described here are fresh, clear, abyssal tholeiitic basalt glasses that were quenched at near liquidus temperatures. They are partially palagonitized around their margins and in fractures. The palagonite is partially altered to smectite, and some fractures are filled with zeolite. The phenocrysts are plagioclase and olivine, which comprise approximately $5 \%$ and $3 \%$ of the sample from Site 320, respectively. Of the various samples from Hole $319 \mathrm{~A}$, none contain $>5 \%$ phenocrysts; the plagioclase:olivine ratio is about 3:1. Some phenocrysts contain glass inclusions. Phenocrysts occur individually throughout the glasses or together as glomeroporphyritic clusters (Figure 1). In these clusters, plagioclase phenocrysts occupy a more central position from which plagioclase needles tend to radiate and around which equant olivines are disposed. An opaque

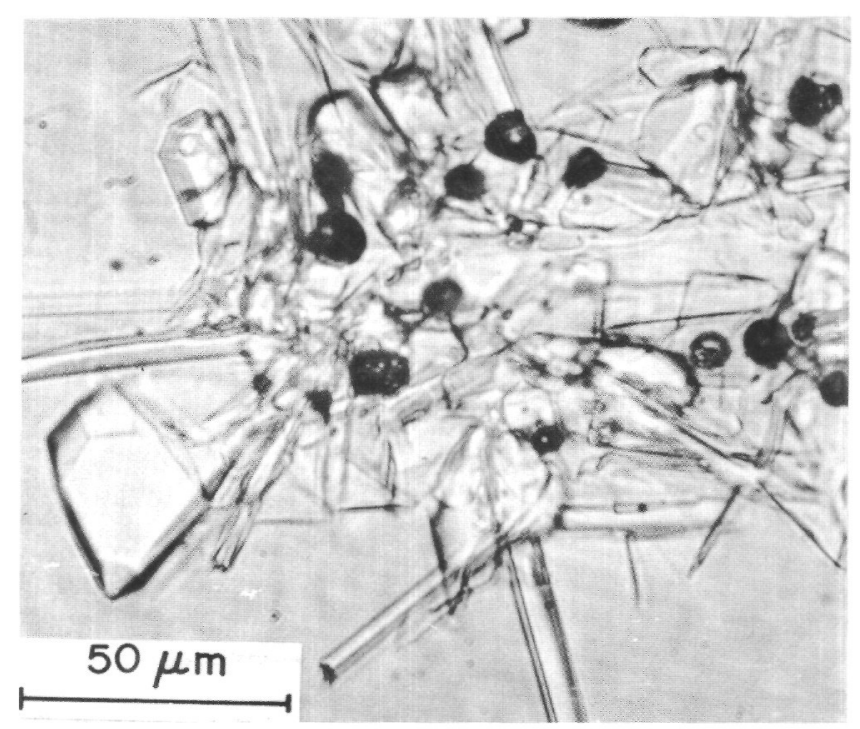

Figure 1. Cluster of plagioclase (elongate) and olivine (equant) crystals in glass. The dark spots are vesicles. Plane light. Sample 320-3-1, 100-106. 
"glass" forms a thin rind around all phenocrysts within $5 \mathrm{~mm}$ of pillow edges. Such "glass" is actually a microcrystalline aggregate (Yeats et al., 1973) and represents an intermediate step in the development of a dark, variolitic texture of the inner margins of pillows from the clear glass of their outer margins.

\section{Plagioclase}

Plagioclase at Site 320 occurs in two distinct size and compositional populations, namely as tabular laths (An ${ }_{73-76}$ ) 0.6-1.2 $\mathrm{mm}$ long and needles (An67-72.5) generally $<0.5 \mathrm{~mm}$ long. The bimodal distribution of plagioclase compositions is illustrated in Figure 2, and representative microprobe analyses are presented in Table 1. Except for their rims, laths are homogeneous or show slight oscillatory zoning. The outer 10-20 $\mu \mathrm{m}$ of the larger phenocrysts are commonly normally zoned in a range of 2-4 mole \% An, but some rims are enriched in Ca (for example, the grain analyzed in Columns 1 and 2, Table 1). Although most small plagioclase phenocrysts are zoned, some show fine oscillatory zoning. That simple normal zoning is not ubiquitous to all rims, and that even small crystals can show complex zoning, suggest that zoning in plagioclase is partly controlled by crystal growth kinetics (Bottinga et al., 1966).

Plagioclases were also analyzed for $\mathrm{Fe}$ and $\mathrm{Mg}$. Their $\mathrm{Mg}$ contents range from 0.11 to $0.16 \mathrm{wt} \%$ and show no regular variation with $\% \mathrm{An}$. $\mathrm{Fe}$, on the other hand, is enriched in the more sodic compositions, ranging from 0.30 to $0.44 \mathrm{wt} \%$ in laths and from 0.48 to $0.54 \mathrm{wt} \%$ in needles. In the glasses from Hole $319 \mathrm{~A}$, the largest plagioclase phenocrysts are $0.4 \mathrm{~mm}$ long but most commonly appear as $<0.2 \mathrm{~mm}$ needles. Their compositions vary from $\mathrm{An}_{74.5-64.3}$. The $\mathrm{Mg}$ concentrations are uniformly $\sim 0.12 \mathrm{wt} \%$, whereas the Fe contents vary widely (0.41-0.74 wt\%).

\section{Olivine}

Olivines occur as equant or, rarely, elongate euhedra. Some of the larger "lantern" crystals (Bryan, 1972) enclose diamond-shaped glass inclusions, and some are embayed at their edges by plagioclase euhedra. Representative olivine analyses are presented in Table 1. Site 320 olivines are typically $\sim 0.05-0.3 \mathrm{~mm}$ in diameter,

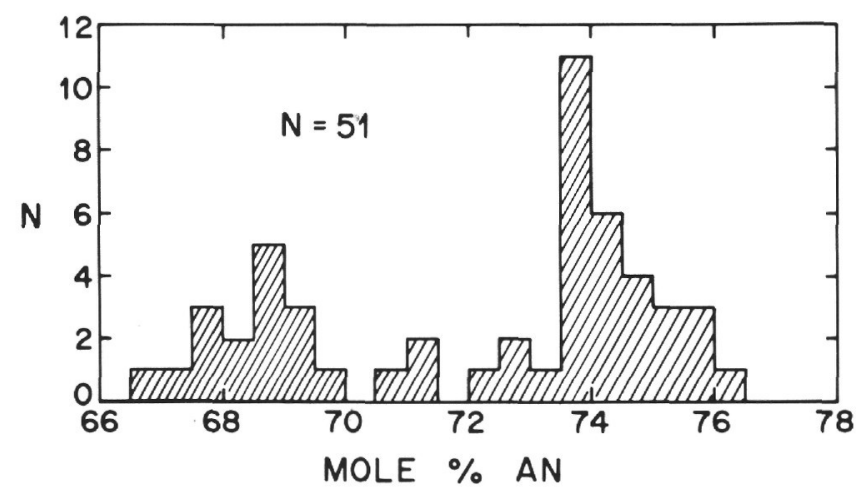

Figure 2. Frequency distribution of plagioclase compositions in Site 320. $N$ is the total number of spot analyses, randomly distributed among 19 crystals. unzoned, and homogeneous from grain to grain (Fo84.5). The olivines of Hole 319A glasses are mostly smaller than $50 \mu \mathrm{m}$. They exhibit little zoning but show minor compositional differences from grain to grain (Fo82-84). This compositional variation presumably reflects olivine growth at slightly differing times, quenching near liquidus temperatures, and no subsolidus olivine-glass reequilibration.

\section{Glass}

Glass compositions are given in Table 2. Each analysis is an average of 10 random spot analyses. A homogeneity index is also reported for the data. These values show that the glasses are homogeneous. Chemical gradients in the glasses were sought in the vicinity of phenocrysts and sulfide-bearing vesicles, but none were found.

The glass compositions show that these rocks are typical low-K ocean basin tholeiites and have sulfur concentrations that are similar to or slightly higher than many other glassy basalts erupted in the abyssal environment. For example, the average sulfur concentration of glassy Reykjanes Ridge basalts erupted in $>200$ meters of water depth is 932 ppm (Moore and Schilling, 1973). Moore and Fabbi (1971), from data on glassy basalts from other deep-sea localities, suggest that juvenile sulfur contents of tholeiitic basalts are $800 \pm 150$ ppm. On the other hand, recent data of Anderson (1974) suggest that sulfur concentrations in glasses of abyssal basalts and in glass inclusions in phenocrysts from other volcanics are usually in the range of $600-1800 \mathrm{ppm}$. In any case, sulfur solubility in mafic melts depends principally on $\mathrm{T}$, for, $\mathrm{fs}_{2}$, and $\mathrm{FeO}$ content of the magma as well as on confining pressure (Haughton et al., 1974; Katsura and Nagashima, 1974). Whatever the values of these variables, the presence of sulfide phases in the Leg 34 rocks means that the melt was saturated in sulfur at the time of eruption. The likelihood that at least some sulfide separated from the melt prior to eruption is demonstrated below; thus, whether or not these high sulfur concentrations approach juvenile values depends on how much sulfide may have settled in the preeruption chamber. Although our data do not allow us to evaluate this, the quenched nature of these rocks makes it unlikely that any of the sulfur came from sea-water contamination.

\section{Sulfide Globules}

Sulfide globules exist in samples from both DSDP Holes 320 and 319A. Although immiscible sulfides are common in large basic layered complexes, rarely have they been reported in basalts. To our knowledge they have been described only in some subaerial Hawaiian lavas by Skinner and Peck (1969) and Desborough et al. (1968), in a basalt glass dredged from the Juan de Fuca Ridge by Moore and Calk (1971), and in some lavas from Mt. Shasta, Kilauea, and Iceland by Anderson (1974). Also, some of the FAMOUS project lavas contain globules (J.G. Moore, personal comm., 1974). Globules are much better developed at Site 320 than in glass fragments from Hole 319A. In the former, we have found four large globules in five thin sections (each sec- 
TABLE 1

Representative Microprobe Analyses of Phenocrysts in Samples from DSDP Sites 320 and 319A

\begin{tabular}{lcccccc}
\hline & 1 & 2 & 3 & 4 & 5 & 6 \\
\hline $\mathrm{SiO}_{2}$ & 49.9 & 49.6 & 51.6 & 50.4 & 39.4 & 39.0 \\
$\mathrm{Al}_{2} \mathrm{O}_{3}$ & 31.6 & 31.7 & 20.0 & 30.8 & & \\
$\mathrm{FeO}$ & $0.43^{\mathrm{a}}$ & $0.52^{\mathrm{a}}$ & $0.64^{\mathrm{a}}$ & $0.63^{\mathrm{a}}$ & 14.8 & 17.0 \\
$\mathrm{MnO}$ & & & & & 0.24 & 0.28 \\
$\mathrm{NiO}$ & & & & & 0.16 & 0.10 \\
$\mathrm{MgO}$ & 0.20 & 0.19 & 0.22 & 0.20 & 45.0 & 43.3 \\
$\mathrm{CaO}$ & 15.1 & 15.4 & 13.9 & 14.3 & 0.32 & 0.32 \\
$\mathrm{Na}_{2} \mathrm{O}$ & 2.97 & 2.67 & 3.45 & 3.37 & & \\
$\mathrm{~K}_{2} \mathrm{O}$ & 0.01 & 0.01 & 0.07 & 0.01 & & \\
Total & 100.2 & 100.1 & 99.9 & 99.7 & 99.9 & 100.0
\end{tabular}

Cation proportions (plagioclase, 8 oxygens; olivine, 4 oxygens)

$\begin{array}{lllllll}\mathrm{Si} & 2.2780 & 2.2665 & 2.3535 & 2.3091 & 0.9921 & 0.9905 \\ \mathrm{Al} & 1.6960 & 1.7086 & 1.6145 & 1.6627 & & \\ \mathrm{Fe} & 0.0163 & 0.0199 & 0.0243 & 0.0240 & 0.3118 & 0.3609 \\ \mathrm{Mn} & & & & & 0.0051 & 0.0060 \\ \mathrm{Ni} & & & & & 0.0033 & 0.0021 \\ \mathrm{Mg} & 0.0137 & 0.0131 & 0.0151 & 0.0133 & 1.6872 & 1.6412 \\ \mathrm{Ca} & 0.7381 & 0.7524 & 0.6769 & 0.7003 & 0.0085 & 0.0088 \\ \mathrm{Na} & 0.2631 & 0.2366 & 0.3052 & 0.2996 & & \\ \mathrm{~K} & 0.0006 & 0.0007 & 0.0043 & 0.0007 & & \end{array}$

Mole \% end member

\begin{tabular}{lrrrrrr}
$\mathrm{An}$ & 73.7 & 76.0 & 68.6 & 70.0 & Fo 84.4 & 82.0 \\
$\mathrm{Ab}$ & 26.2 & 23.9 & 30.9 & 29.9 & Fa 15.6 & 18.0 \\
$\mathrm{Or}$ & 0.1 & 0.1 & 0.4 & 0.1 & & \\
\hline
\end{tabular}

Note: 1 = Center of a plagioclase 1ath, Sample 320-3-1, 100-106; 2 = Same grain, $15 \mu \mathrm{m}$ from edge; $3=$ plagioclase needle in glass, Sample 320-3-1, 100-106; 4 = Plagioclase, Hole 319A core; 5 = Typical olivine, Sample 320-3-1, 100-106; 6 = Typical olivine, Hole 319A core.

${ }^{\mathrm{a}} \mathrm{All} \mathrm{Fe}$ as $\mathrm{FeO}$.

TABLE 2

Microprobe Glass Analyses, Average of 10 Random $30 \mu \mathrm{m}$ Diameter Spots

\begin{tabular}{lrrrr}
\hline & 320 & $\sigma / \sqrt{N^{\mathrm{a}}}$ & $319 \mathrm{~A}$ & $\sigma / \sqrt{N}$ \\
\hline $\mathrm{SiO}_{2}$ & 49.96 & $2.4^{\mathrm{b}}$ & 50.04 & 0.6 \\
$\mathrm{TiO}_{2}$ & 1.54 & 1.1 & 1.90 & 0.7 \\
$\mathrm{Al}_{2} \mathrm{O}_{3}$ & 14.79 & 1.2 & 13.80 & 2.0 \\
$\mathrm{FeO}$ & $9.79^{\mathrm{c}}$ & 1.1 & $11.03^{\mathrm{c}}$ & 1.1 \\
$\mathrm{MnO}$ & 0.18 & & 0.22 & \\
$\mathrm{MgO}$ & 7.37 & 1.1 & 6.77 & 0.9 \\
$\mathrm{CaO}$ & 12.06 & 1.1 & 11.99 & 1.0 \\
$\mathrm{Na}_{2} \mathrm{O}$ & 2.78 & 1.0 & 2.82 & 1.2 \\
$\mathrm{~K}_{2} \mathrm{O}$ & 0.08 & & 0.09 & \\
$\mathrm{P}_{2} \mathrm{O}_{5}$ & 0.16 & & 0.17 & \\
$\mathrm{~S}$ & 0.12 & & 0.15 & \\
Total & 98.83 & & 98.98 & \\
\hline
\end{tabular}

$\mathrm{a}_{\sigma / \sqrt{N}}$ is a measure of homogeneity, where $\sigma$ is the standard deviation of the 10 sets of counts and $N$ is the mean count. See Liebhafsky et al. (1960), ch. 10, for a discussion of this topic.

$\mathrm{b}_{\mathrm{The}}$ standard deviation in terms of $\mathrm{SiO}_{2}=$ $0.28 \mathrm{wt} \%$.

${ }^{\mathrm{c}} \mathrm{All} \mathrm{Fe}$ as $\mathrm{FeO}$. tion approximately $100 \mathrm{~mm}^{2}$ ). The large globules have diameters of $14,24,38$, and $48 \mu \mathrm{m}$ and numerous small globules are $\leq 4 \mu \mathrm{m}$ wide. Since we view only one plane through a spherical globule, these diameters are minimal. In any event, globules are an extremely minor component of the rock. From globule counts in two thin sections the globule volume is $\sim 10 \mathrm{ppm}$ of the glass.

Figures $3 \mathrm{a}$ and $4 \mathrm{a}$ are, respectively, reflected light photomicrographs of the largest globule and of a globule $4 \mu \mathrm{m}$ in diameter enclosed in glass embaying a plagioclase phenocryst. They illustrate the fact that the globules are essentially spherical, although larger ones have irregular edges. In many cases, globules exhibit an interstitial relationship with plagioclase phenocrysts (Figure 4b). These observations demonstrate that the globules are magmatic, resulting from immiscibility between sulfide and silicate liquids; that they existed as liquids during plagioclase crystallization; and that globule sulfide crystallized after the larger plagioclase phenocrysts. Therefore, a liquid sulfide phase existed in the magma prior to its eruption, and it is likely that at least some of this sulfide must have settled in the preeruption chamber. Also relevant to this point is that many Site 320 globules, both large and small, are immediately adjacent to plagioclases, probably because 


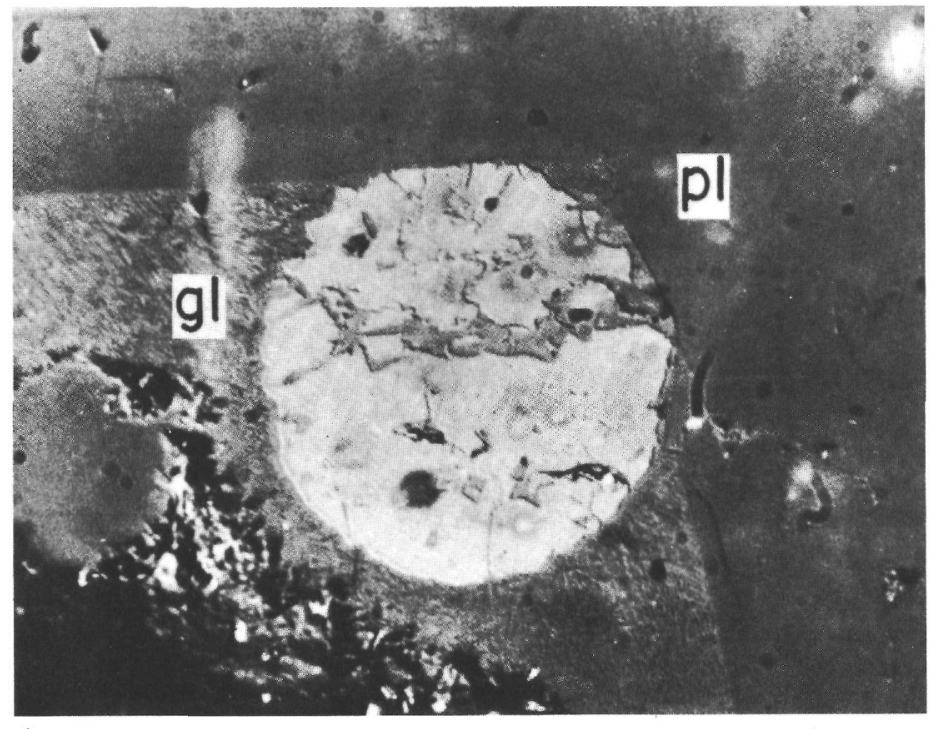

A

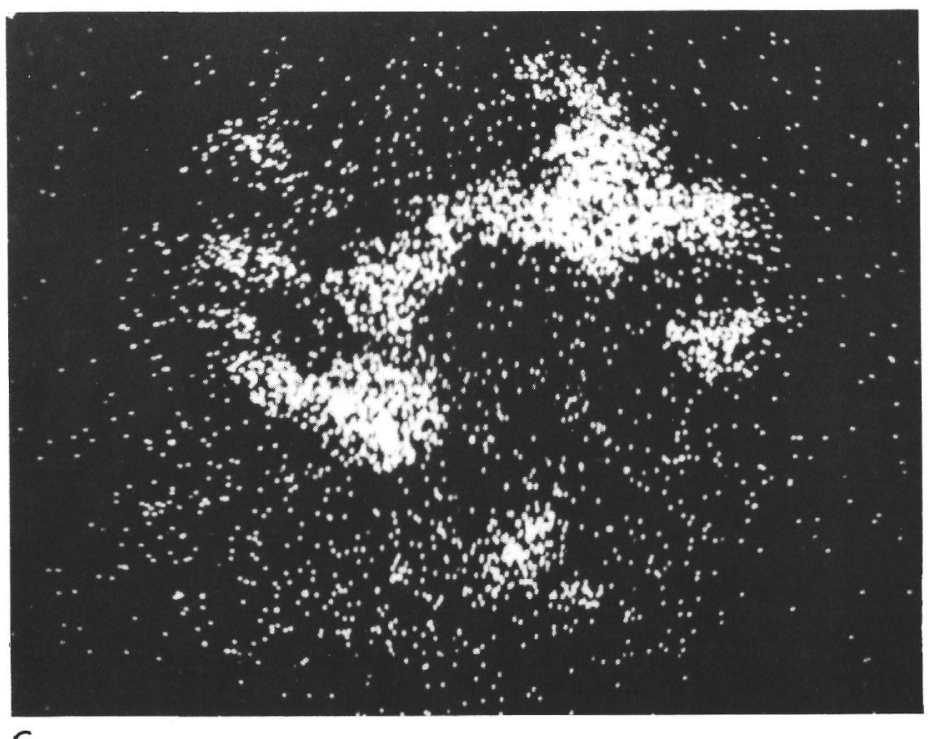

C

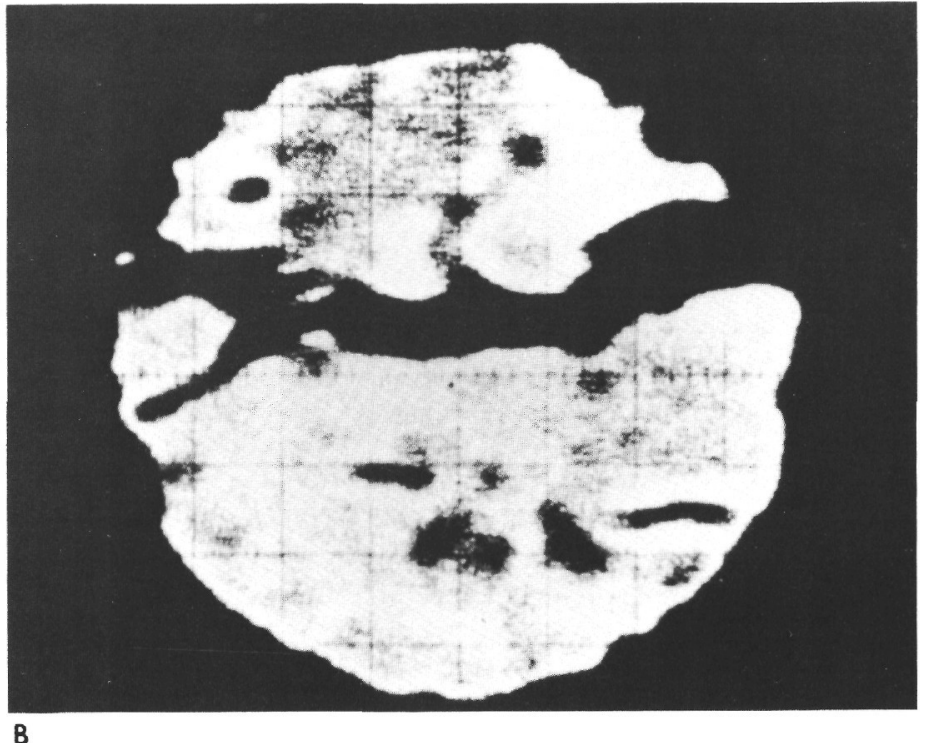

B

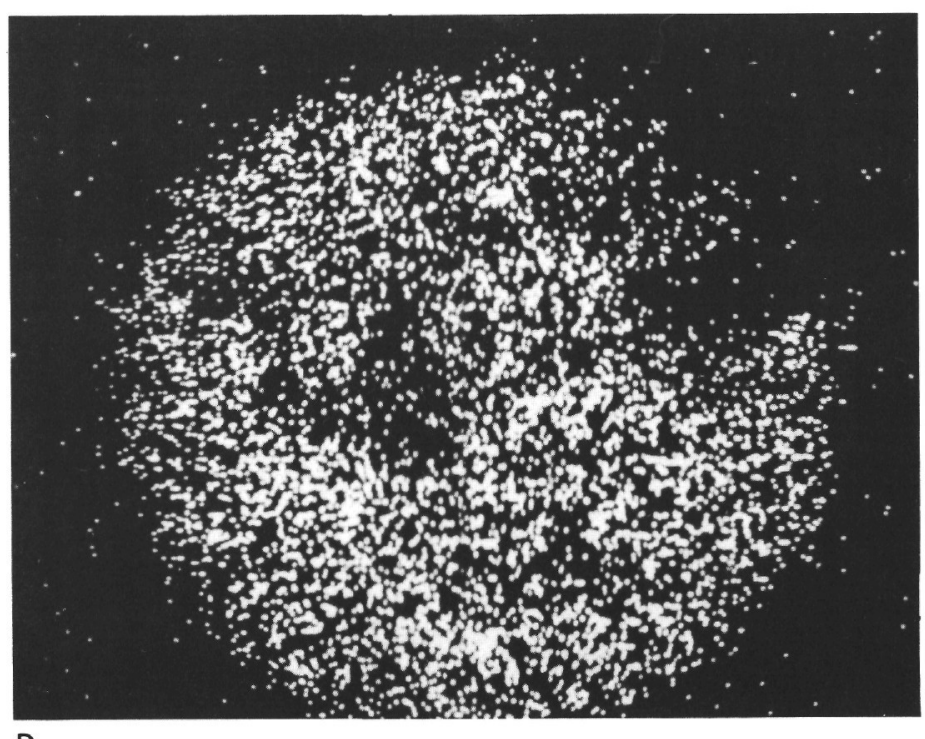

D

Figure 3. Sulfide globule, $48 \mu \mathrm{m}$ wide. Sample 320-3-1, 100-106. (a) Reflected light photomicrograph. The fracture in the globule is filled with silicate glass. Note the flat edge of the globule against one of the plagioclase grains and its embayment of the other. $P l=$ plagioclase; $g l=$ silicate glass. (b) Beam scanning reverse image sample current display, where light intensity is proportional to mean atomic number. (c) Beam scanning X-ray intensity displays of Cu and (d) of Ni, showing that the globule has exsolved into discrete Cu-and Ni-rich phases. See Table 3 for compositional data. All beam scanning displays were produced at $20 \mathrm{kv}$ and 40 namps sample current. 


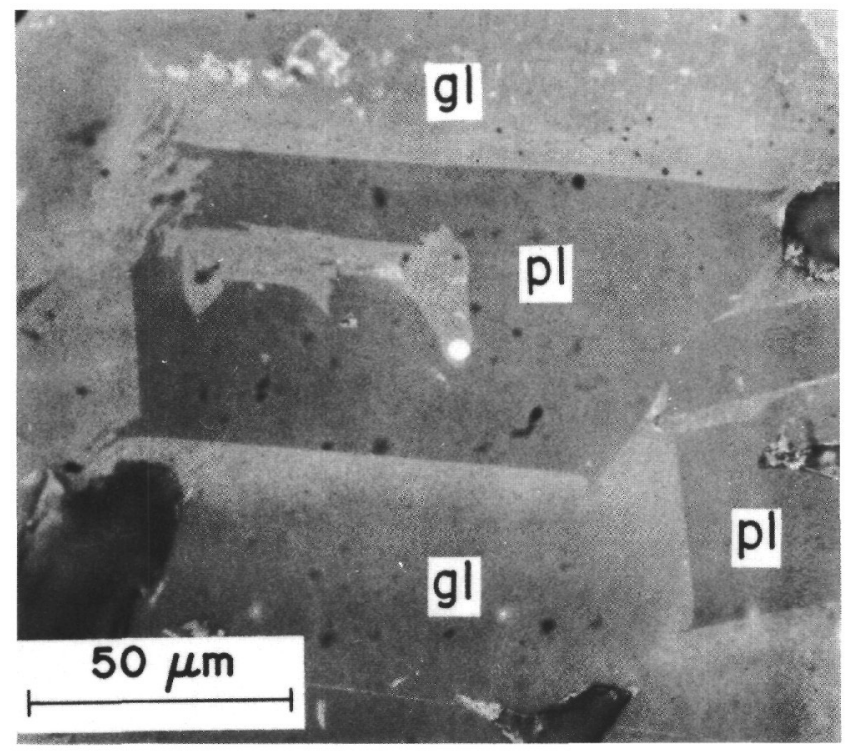

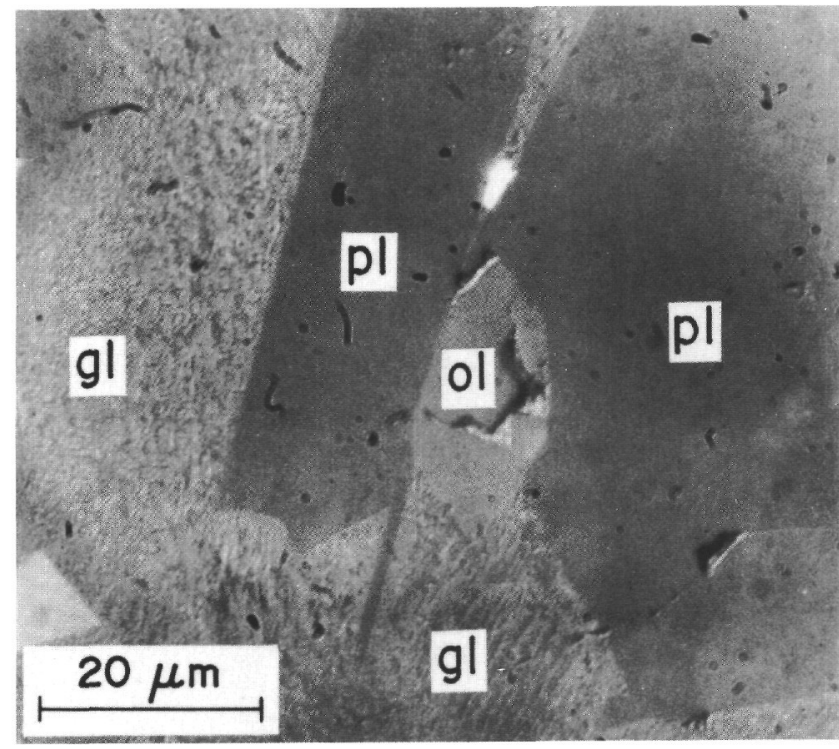

Figure 4. Reflected light photomicrographs (a) of a 4 um sulfide globule enclosed in glass which embays a plagioclase microphenocryst, and (b) of a small globule whose shape appears to have been controlled by the presence of the adjacent plagioclase microphenocrysts, Sample 320-3-10, 100-106. These relationships suggest that a sulfide liquid existed in the magma prior to eruption. $P l=$ plagioclase $; g l=$ silicate glass; ol = olivine .

TABLE 3

Sulfide Analyses, Sample 320-3-1, 100-106

\begin{tabular}{lcccccccc}
\hline & 1 & 2 & 3 & 4 & 5 & 6 & 7 & 8 \\
\hline $\mathrm{S}$ & 37.4 & 35.1 & 37.0 & 36.0 & 33.0 & 35.2 & 35.6 & 34.3 \\
$\mathrm{Fe}$ & 50.8 & 37.0 & 49.0 & 51.0 & 38.7 & 47.6 & 45.3 & 47.6 \\
$\mathrm{Ni}$ & 9.1 & 3.3 & 8.3 & 11.0 & 2.8 & 8.7 & 6.9 & 7.8 \\
$\mathrm{Cu}$ & 1.1 & 23.1 & 4.1 & 0.6 & 23.5 & 7.0 & 8.9 & 6.6 \\
$\mathrm{Co}$ & 0.28 & 0.11 & 0.26 & 0.28 & 0.18 & 0.25 & 0.23 & 0.27 \\
$\mathrm{Mn}$ & 0.03 & 0.05 & 0.03 & 0.04 & 0.05 & 0.04 & 0.05 & 0.04 \\
$\mathrm{Zn}$ & 0.00 & 0.10 & 0.02 & 0.00 & 0.05 & 0.02 & 0.02 & 0.03 \\
Total & 98.7 & 98.8 & 98.7 & 98.9 & 98.3 & 98.8 & 97.0 & 96.6 \\
\hline
\end{tabular}

Note: 1 = Ni-rich phase (monosulfide solid solution [mss] of globule of Figure $3 \mathrm{a}$, average of 5 spots; $2=$ Cu-rich phase of same globule; $3=$ Bulk composition, calculated from analyses 1 and 2; 4 Mss of $38 \mu \mathrm{m}$ globule; $5=$ Cu-rich phase of same globule; $6=$ Bulk composition, calculated from analyses 4 and $5 ; 7,8=$ Bulk composition of smaller globules, averages of several spots.

they adhered to plagioclase during the magma's ascent to the surface. Again, the implication is that sulfides which did not adhere to light grains rapidly settled in the subsurface chamber.

The gray material filling the fracture of the globule of Figure $3 \mathrm{a}$ is silicate glass (see also Figure $3 \mathrm{~b}$ ), which means that the sulfide phase must have been at least partially solidified in the presence of silicate liquid. However, that the sulfide phase was erupted as a liquid can be demonstrated by consideration of eruption temperature and sulfide liquid stability. Using the average plagioclase needle composition and glass data of Table 2, the eruption temperature calculated from plagioclase-liquid equilibria (Mathez, 1973, eq. 7a) is about $1195^{\circ} \mathrm{C}$. Compositions of sulfides from Site 320 (given in Table 3 and discussed in detail below) fall within the $\mathrm{Ni}-\mathrm{Cu}-\mathrm{Fe}-\mathrm{S}$ system, which has been studied experimentally (Yund and Kullerud, 1966; Kullerud et al., 1969; Craig and Kullerud, 1969). The highest temperature crystalline phase in this system is pyrrhotite, which appears at $1192^{\circ} \mathrm{C}$ (see Kullerud et al., 1969, figs. 5 and 14).

We have found two globules in Hole 319A glass that are $10 \mu \mathrm{m}$ in diameter; all others are $2-3 \mu \mathrm{m}$ wide. They are seldom adherent on plagioclase and perhaps separated at a later stage in the eruptive history of 319A basalt than in Site 320 lava. Because of the small globule size, we have been unable to produce quantitative analyses of 319A sulfides.

Figure $3 \mathrm{~b}$ is a beam scanning reverse image sample current display (where light intensity is proportional to mean atomic number) of the largest globule (shown in Figure $3 \mathrm{a}$ ). The $\mathrm{Cu}$ and $\mathrm{Ni}$ beam scanning $\mathrm{X}$-ray images of Figures $3 \mathrm{c}$ and $3 \mathrm{~d}$ show that two distinct sulfide phases exist. The predominant one is a monosulfide solid solution (termed Mss, following Kullerud et al., 
1969-probably pyrrhotite) in which $\mathrm{Ni}$ varies from 813 wt $\%$ and in which $0.5 \%-2 \% \mathrm{Cu}$ is dissolved. The other phase contains about $23 \mathrm{wt} \% \mathrm{Cu}$ and appears to be either a high-temperature chalcopyrite or a member of the cubanite solid solution series. These phases exsolved at subsolidus temperatures (see below). In no globule has magnetite been identified.

Sulfide analyses from Site 320 are presented in Table 3 . It is rather difficult to produce good microprobe analyses of the sulfides. Problems that make this so are (1) the globules probably are not homogeneous with respect to $\mathrm{S}, \mathrm{Fe}, \mathrm{Ni}$, and $\mathrm{Cu}$ on the micron level because it is difficult to reproduce analyses of the same spot by returning to it a second time. This combination of elements requires two runs on our probe; thus, even small errors in the relocation of spots may introduce errors in the analyses. (2) Micron-size inclusions of another phase, probably silicate glass, are common. The low totals of these analyses, particularly of analyses of smaller globules, are probably due to excitation of small volumes of silicate glass that exist within and beyond the sulfide phases. For these reasons we report the compositions of sulfide phases in only the larger globules. Also, it is only in the larger globules that the phases are distinct and relatively homogeneous. Estimated bulk compositions of these globules are also reported and are calculated from the relative areas of the two phases. The estimates assume that relative areas are representative of volumetric relations. This and the problems described above may explain the differences in bulk compositions reported in Table 3.

In addition to major elements, the sulfides were analyzed for $\mathrm{Mn}, \mathrm{Co}$, and $\mathrm{Zn}$. The data in Table 3 show that $\mathrm{Zn}$ is partitioned into the $\mathrm{Cu}$-rich phase and $\mathrm{Co}$ into Mss.

Experimental data in the Ni-Cu-Fe-S system (Yund and Kullerud, 1966; Kullerud et al., 1969; Craig and Kullerud, 1969) can be used to interpret the subsolidus sulfide phase relations within the globules. In Figure 5 the compositions of the $\mathrm{Ni}$ - and $\mathrm{Cu}$-rich phases and estimated bulk compositions are projected onto the $700^{\circ} \mathrm{C}$ isothermal $\mathrm{Cu}-\mathrm{Fe}-\mathrm{S}$ surface. The projection is made at constant $\mathrm{S}$ rather than directly away from the $\mathrm{Ni}$ apex of the tetrahedron; that is, $\% \mathrm{Fe}+\% \mathrm{Cu}=100-\% \mathrm{~S}$. It is clear that the bulk compositions lie within or close to the narrow field of chalcopyrite + pyrrhotite stability; because of the nature of the projection, they probably all lie within this field in the tetrahedron interior. In any event, compositions of the globule phases are very close to those which should be in equilibrium at $700^{\circ} \mathrm{C}$ according to the experimental data. When chalcopyrite first appears in this system $\left(\mathrm{T} \sim 960^{\circ} \mathrm{C}\right)$, it contains $\sim 32.5 \mathrm{wt}$ $\% \mathrm{Cu}$. With falling temperature, chalcopyrite solid solution can accept larger quantities of the pyrrhotite component, so that the least $\mathrm{Cu}$-rich chalcopyrite at $700^{\circ} \mathrm{C}$ contains about $25 \% \mathrm{Cu}$. At still lower temperatures the maximum amount of pyrrhotite that can be dissolved in chalcopyrite solid solution (and at lower temperature cubanite solid solution) remains approximately constant. Therefore, the presence of $\mathrm{Cu}$-rich phases of the compositions shown means that the last temperature of equilibration of the globule phase is $5700^{\circ} \mathrm{C}$ and that

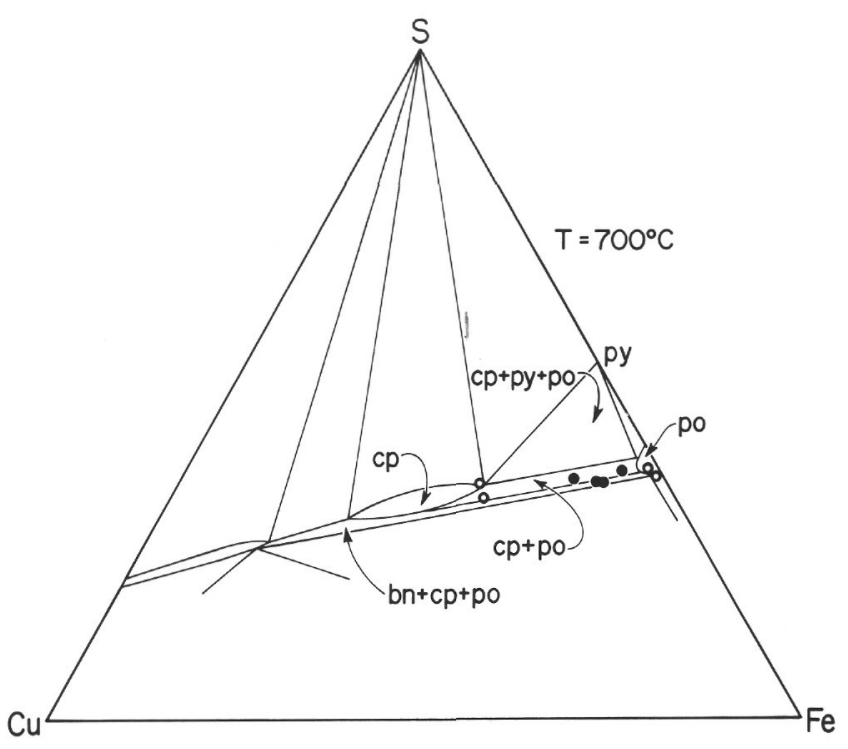

Figure 5. Generalized system Cu-Fe-S at $700^{\circ} \mathrm{C}$ (Kullerud et al., 1969, fig. 8). Po = pyrrhotite; py = pyrite; $c p=$ chalcopyrite solid solution; $b n=$ bornite solid solution. Open circles = compositions of sulfides in Site 320 globules; solid circles = estimated bulk compositions of globules. Data are from Table 3; see text for method of projection.

sulfide re-equilibration is extremely rapid with falling temperature.

Globule Mss and bulk compositions fall approximately within the field of Mss stability in the NiFe-S system (Kullerud et al., 1969) from $1100^{\circ} \mathrm{C}$ to $<500^{\circ} \mathrm{C}$ and therefore demonstrate that the Mss with variable $\mathrm{Ni}, \mathrm{Fe}, \mathrm{S}$, and $\mathrm{Cu}$ contents are in internal equilibrium at high temperature.

\section{Vesicles and Sulfide Spherules}

Moore and Calk (1971) have shown that vesicles with sulfide spherules lining their walls are ubiquitous in basalts erupted in the abyssal environment. Reference should be made to their report for discussions of vesicle distribution throughout pillows and their general character in other sea-floor rocks. In the basalts from Hole 319A and Site 320, vesicles comprise $<0.5$ volume $\%$ of the glassy margins of the rocks. Maximum diameter of the vesicles is $\sim 200 \mu \mathrm{m}$, but most are $<80$ $\mu \mathrm{m}$. Smaller ones are more common where they occur among the crystal clusters (Figure 1). Perhaps 30\%-60\% of these contain sulfide spherules. This is difficult to estimate because some vesicles are small and appear dark in transmitted light, and some are filled with smectite. The latter may have embedded in them micron size grains of a yellowish mineral, possibly a sulfide alteration product.

Spherules are distributed regularly on vesicle walls and have a distinct bimodal size distribution, similar to that described by Moore and Calk (1971). The smaller spherules are concentrated at sites furthermost from the larger ones (Figures 6a, d, h, 7a), and no small spherules are found immediately adjacent to the larger ones. This 
suggests that both size populations formed simultaneously. The contact between each spherule and the vesicle wall is a smooth, hemispherical pit, and thus the spherules formed in the liquid state while the silicate was also liquid. The shape of each spherule within the vesicle is equant but irregular and rough (Figure $6 \mathrm{~b}, \mathrm{c}, \mathrm{f}$, h), which probably results from spherule crystallization.

Under high magnification, vesicle walls are seen to be irregular and rough (Figure $6 f$ ) or marked by grooves (Figures 6b, c, h). Some grooves are patterned like a leaf (Figures 6b, c), are equally spaced, and intersect throughgoing grooves at angles of $30^{\circ}-45^{\circ}$. In many cases, the shorter grooves do not connect with the throughgoing grooves, and some appear to consist of coalescing pits. Other grooves seem to occur in pairs; these are gently curved but tangential to the larger spherules, giving the vesicle wall a polygonal or turtleback appearance (Figure 6h). The surface texture of vesicle walls may be an etching phenomenon ( $\mathrm{J}$. Blacic, personal comm., 1974).

Some vesicle walls are covered by an amorphous material (Figures 6b, e, f), possibly smectite. This material postdates the formation of grooves and the formation of the irregular outer boundaries of spherules within the vesicles.

We are unable to produce quantitative microprobe analyses of these spherules because of their small size (1$4 \mu \mathrm{m})$ and the fact that they occur only on curved vesicle walls which cannot be polished in a section for probe analysis. However, some qualitative knowledge of their chemistry can be obtained from X-ray intensity displays of various elements during beam scanning. These are shown in Figures $7 b-d$. The sulfur image (Figure 7b) shows that the small $(<0.5 \mu \mathrm{m})$ as well as large spherules are indeed sulfides since the spot density between the larger spherules within the vesicle is greater than is the glass beyond. The $\mathrm{Cu}$ and $\mathrm{Ni}$ distributions of Figures $7 \mathrm{c}$ and $7 \mathrm{~d}$ demonstrate that these elements occur in substantial concentrations in the spherules. The spherule composition, then, is likely to be close to the estimated bulk composition, as would be expected if all phases were in equilibrium. The spherules are probably pyrrhotites with $5 \%-10 \%$ dissolved $\mathrm{Ni}$ and $\mathrm{Cu}$.

Moore and Calk (1971) suggest that spherules form by reaction of the sulfur in the gas phase and metallic components of the silicate liquid. However, sublimates of gases collected directly over some Hawaiian lavas contain small concentrations of metallic species, including $\mathrm{Fe}, \mathrm{Ni}$, and $\mathrm{Cu}$ (Naughton et al., 1974); and metallic $\mathrm{Fe}$ has been shown to form by vapor phase crystallization in some lunar breccias (Clanton et al., 1974). Therefore, the formation of spherules by condensation from the gas phase deserves consideration.

The presence of some vesicles among glomeroporphyritic clusters (Figure 1) may mean that a gas phase had begun exsolving prior to lava extrusion. The composition of the gas phase, which should be dependent principally on solubilities of the $\mathrm{S}$ species and $\mathrm{CO}_{2}$ in the magma, should change with changing $\mathrm{P}_{\text {total. }}$ Thus, it is not clear exactly when in the eruptive history of these lavas sulfide spherules embedded in vesicle walls formed.

\section{PARAGENESIS}

The petrographic and chemical data presented above suggest the following evolution: Prior to their eruptions at Sites 319 and 320, the silicate liquids contained plagioclase (which was probably the liquidus phase), olivine, and an immiscible sulfide liquid. The presence of the latter in the pre-eruption magma is implied by the interstitial relationship of globules with plagioclase (Figures $3 \mathrm{a}, 3 \mathrm{~b}$ ) and by their apparent adherence on plagioclase surfaces in samples from Site 320. An eruption temperature of $1195^{\circ} \mathrm{C}$ is calculated from plagioclase thermometry. Vesicles formed as a sulfurrich gas phase exsolved during eruption but perhaps also in a deeper environment. Sulfide spherules precipitated from the gas on the vesicle walls while the silicate remained liquid. After the eruption, sulfide globules froze before the silicate liquid. In the rapidly quenched pillow rim, the sulfides in globules underwent subsolidus re-equilibration, which resulted in exsolution of $\mathrm{Ni}$-rich Mss and an Fe-rich chalcopyrite (or cubanite). The kinetics of sulfide subsolidus re-equilibration are such that the equilibrium temperature indicated from compositions of the sulfide phases is $\leq 700^{\circ} \mathrm{C}$, probably in the range $500^{\circ}-700^{\circ} \mathrm{C}$.

\section{CONCLUSIONS}

The Leg 34 basalt glasses described in this report are chemically and petrographically typical of other abyssal sea-floor basalt glasses. They contain Ni- and $\mathrm{Cu}$-rich sulfide globules that result from silicate-sulfide liquid immiscibility and have vesicles with well-developed sulfide spherules lining their walls. Paragenetic relations show that an immiscible sulfide liquid existed in at least the Site 320 magma prior to its eruption, showing that the magma was saturated in sulfur at that time and opening the possibility that sulfides concentrated themselves at the floor of the pre-eruption magma chamber. This also means that sulfur contents of the basalt glasses are only minimum juvenile values; that is, how close these reported values are to the juvenile ones depends on the extent of sulfide separation. The sulfide phase relations within the globules show that these phases undergo relatively low temperature $\left(\leq 700^{\circ} \mathrm{C}\right)$ reequilibration, even in rocks quenched from magmatic temperatures to $<500^{\circ} \mathrm{C}$ in some tens of seconds. SEM photographs of sulfide spherules and vesicles show that spherule surfaces within the vesicles are irregular, that vesicle walls exhibit complex groove patterns, and that some vesicle walls are coated with an amorphous material (smectite?) which postdates groove formation. Microprobe data on the spherules suggest that they have a composition similar to the bulk composition of globule sulfides. We agree with Anderson (1974) that sulfur saturation in tholeiitic basalt melts is probably a common circumstance and suggest that other ocean floor basalts be carefully scrutinized for similar features.

\section{ACKNOWLEDGMENTS}

We wish to thank Drs. William E. Benson, John Delaney, Bernard Evans, William Glassley and James G. Moore for their reviews and helpful criticisms of the manuscript and Drs. I.S. McCallum and J. Blacic for particularly valuable dis- 


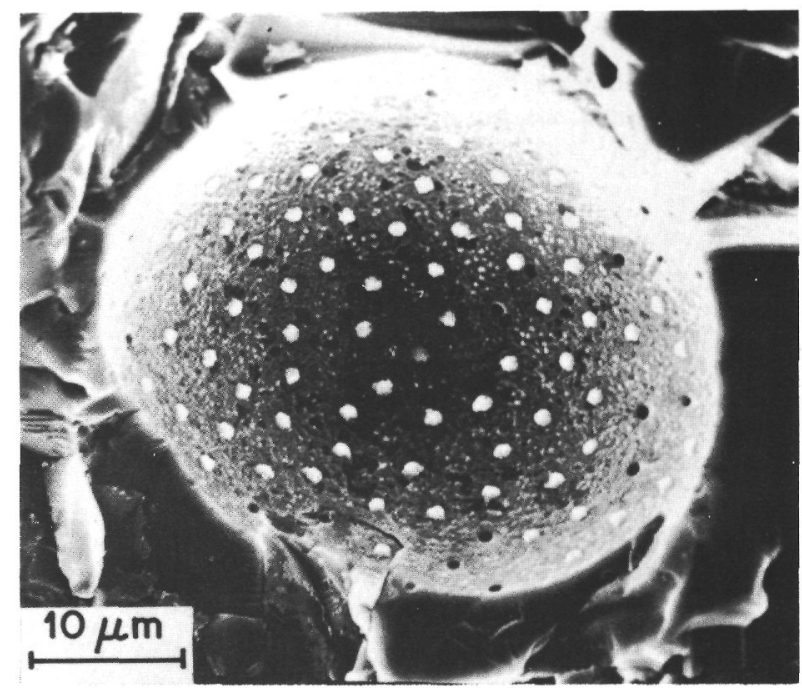

A

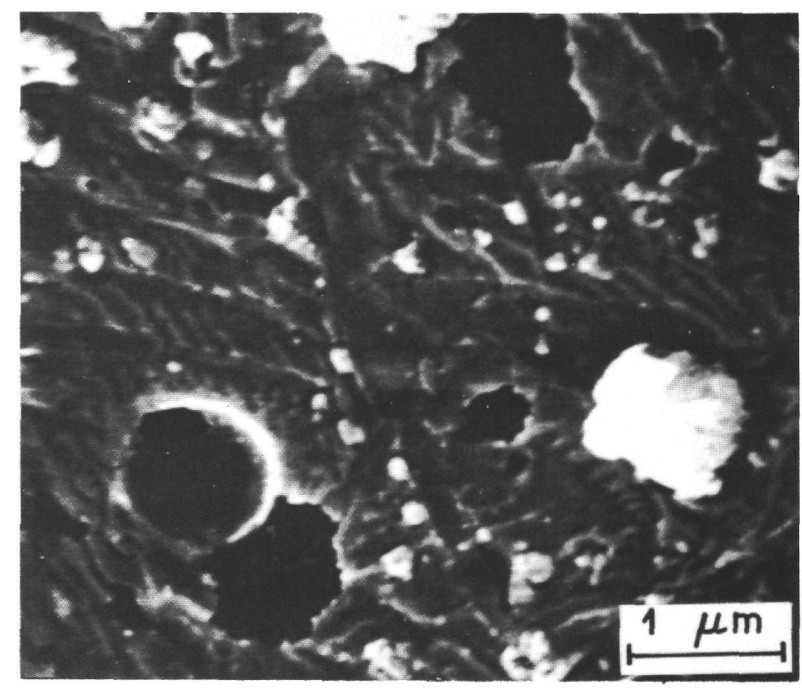

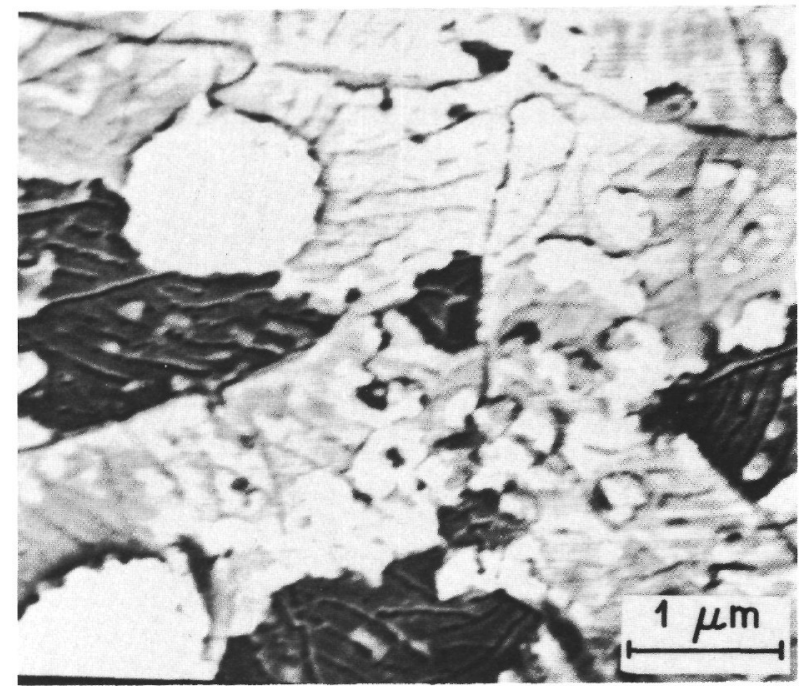

B

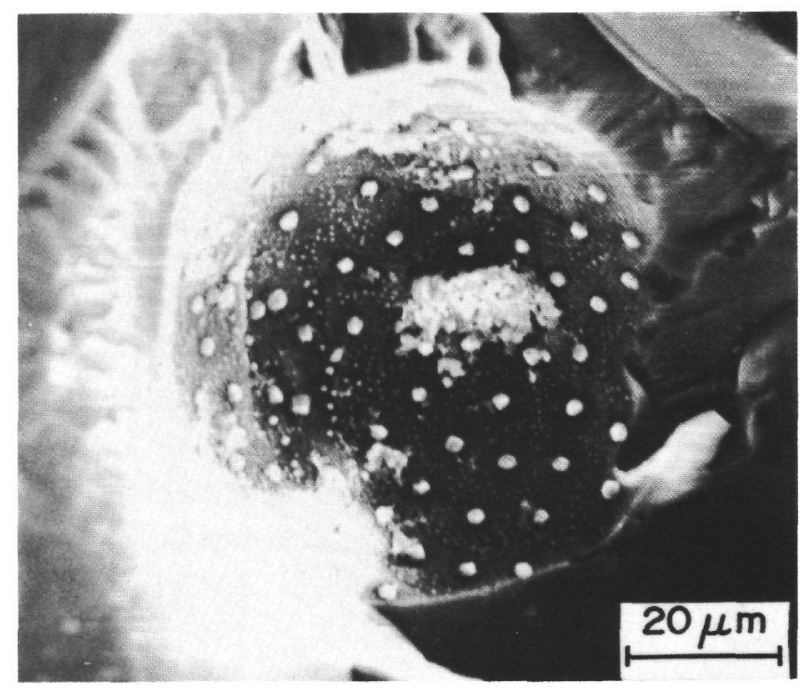

D

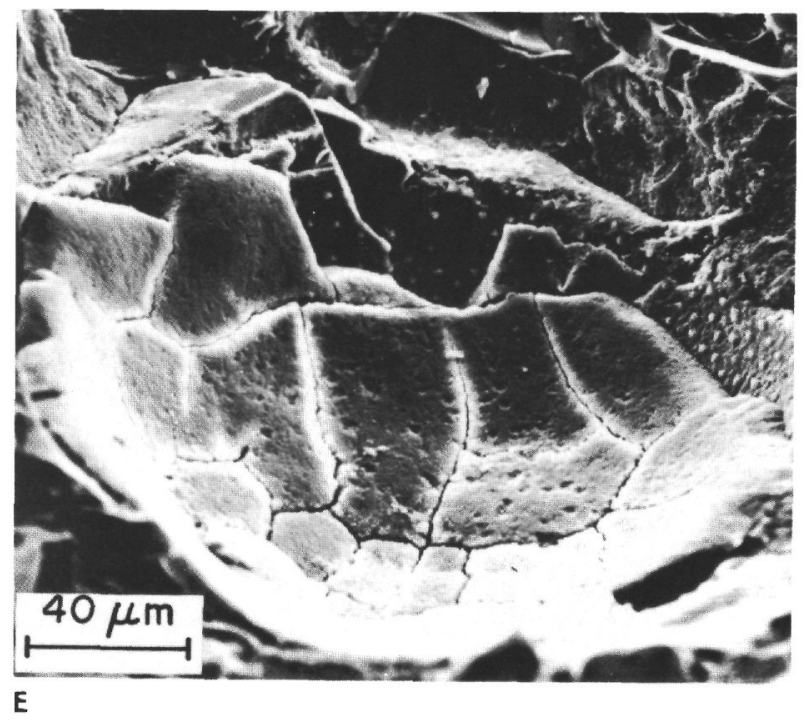

Figure 6. (a) SEM photo of a vesicle in glass, Sample 320-3-1, 100-106. The surface cut is near the edge of the vesicle, thereby permitting greater illumination and magnification of the vesicle wall. Spherules (white in photograph) are in two size populations. Larger spherules are distributed evenly across the vesicle surface. Smaller spherules are concentrated at sites far from larger ones, suggesting that both size populations formed simultaneously. Hemispherical pits locate sites where larger spherules were removed. (b) SEM enlargement of the center of the vesicle shown in 6a. Both large and small spherules are 

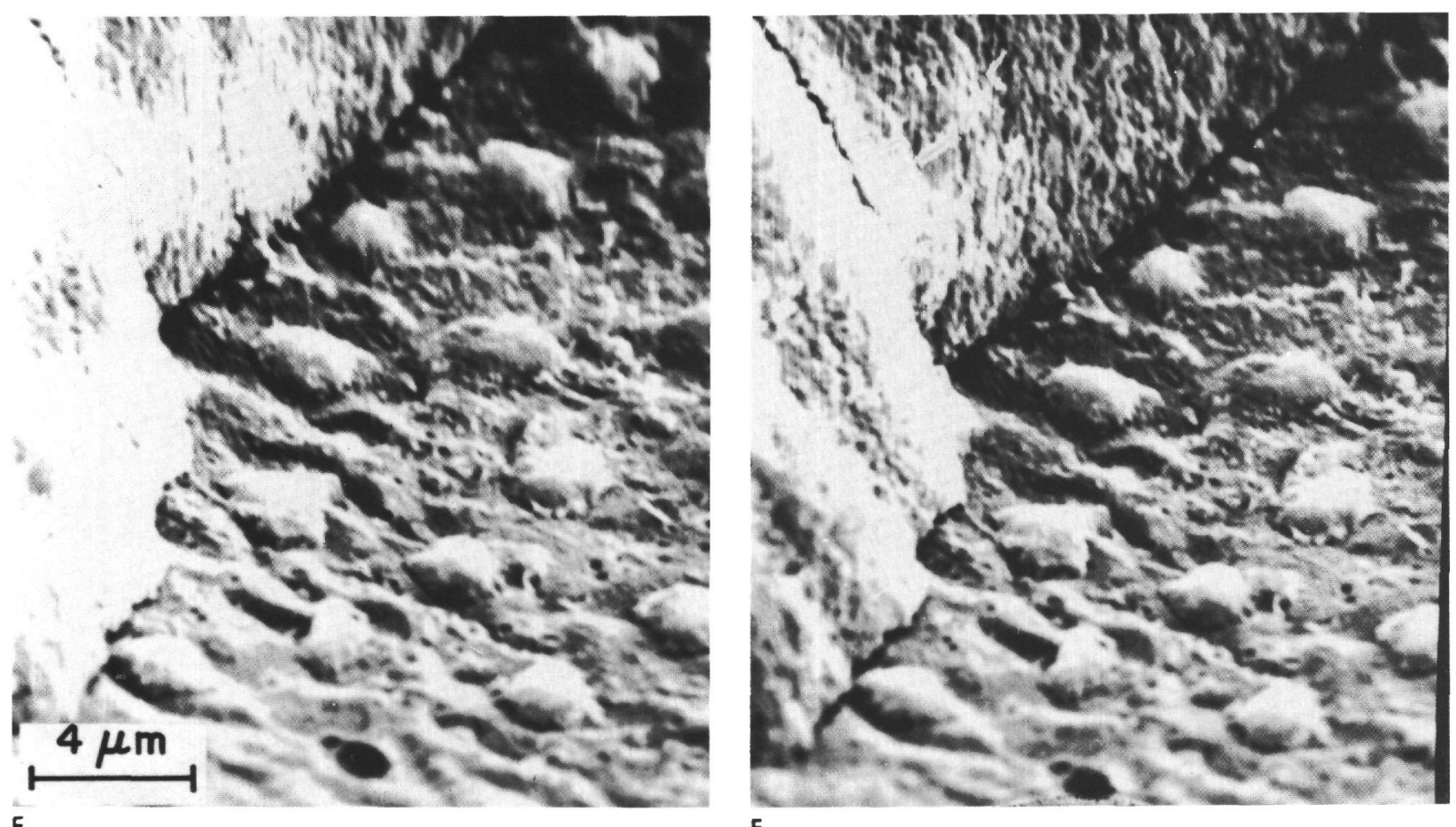

F
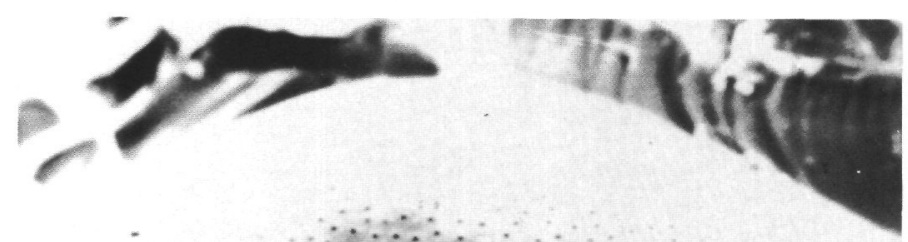

G
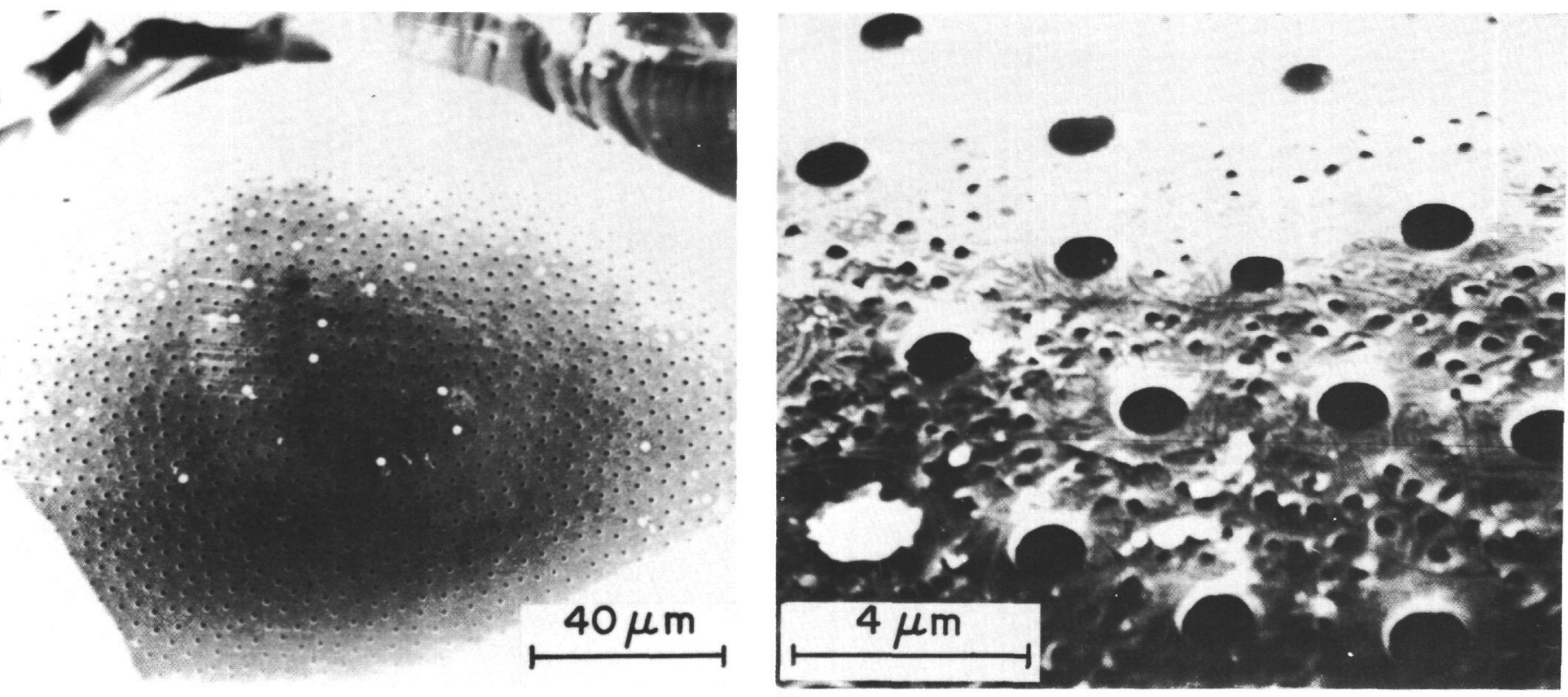

H

irregular in surface morphology. The white coating on the vesicle wall is possibly smectite. Discontinuous grooves mark the vesicle wall; these appear to be equally spaced and make angels of $30^{\circ}-45^{\circ}$ with a throughgoing groove. Locally, the grooves appear to consist of coalescing pits. The grooves may be an etching phenomenon. (c) SEM enlargement of the area just to the right of $6 \mathrm{~b}$, showing detail of two large spherules and many small ones. Note the hemispherical pit where a large spherule was removed. (d) SEM photo of a cut near the edge of a vesicle in glass from Hole $319 \mathrm{~A}$. Note the bimodal size population of spherules; no small spherules are found in the vicinity of the large ones. (e) SEM photograph of a cut near the edge of a vesicle from Site 320. The vesicle is partially lined with (?) smectite, which covers the spherule-dotted surface. (f) SEM stereopair of the lower edge of a vesicle. The vesicle surface is photographed at low beam incidence to show surface relief. The hole at the bottom is the site of a large spherule that was removed; the large number of small pits are sites of small spherules. A coating of (?) smectite clearly postdates spherule formation. (g) SEM photo of a cut near the edge to show detail in the recessed part of the vesicle. Most of the large spherules are removed, showing the hemispherical nature of contact at which spherule is embedded in glass. (h) SEM enlargement near the upper edge of the vesicle in $6 \mathrm{~g}$ showing a bimodal size distribution of spherule populations, the hemispherical shape of the holes for both large and small spherules, and the absence of small spherules in the vicinity of the large ones. The vesicle surface is marked by paired sets of grooves. These grooves are gently curved and are generally tangential to the large spherule sites, giving the vesicle wall a polygonal or "turtleback" appearance. 


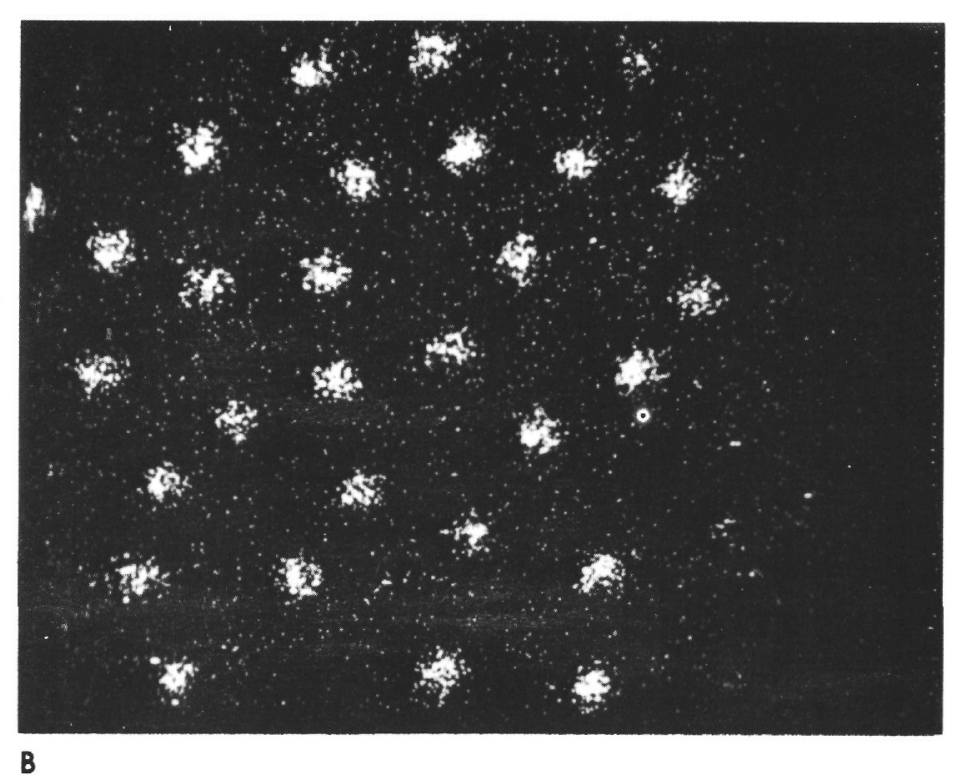

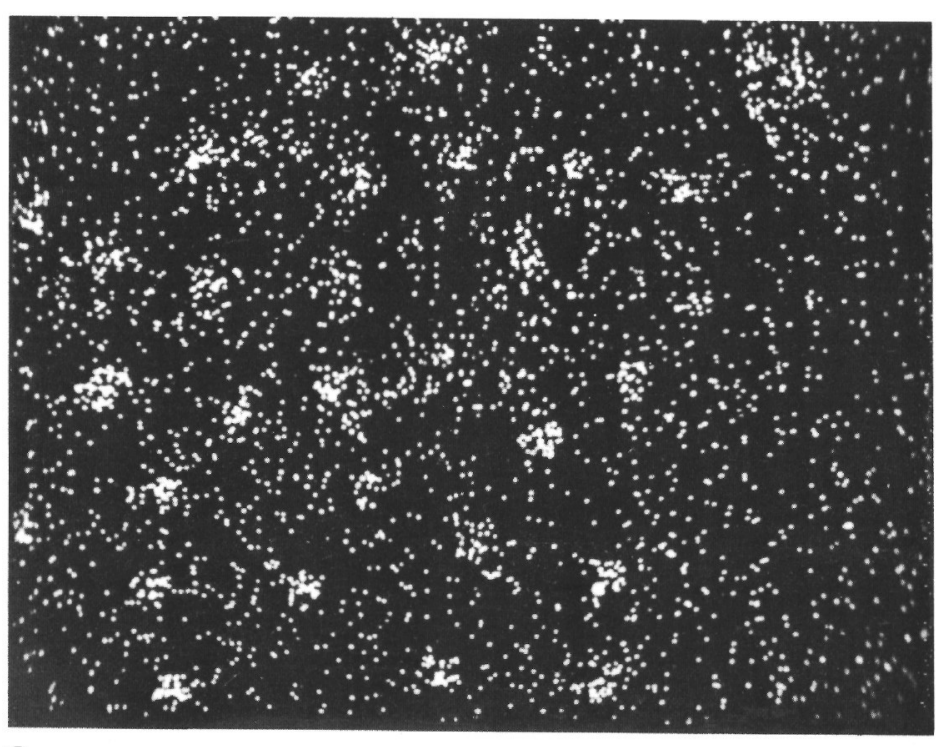

C

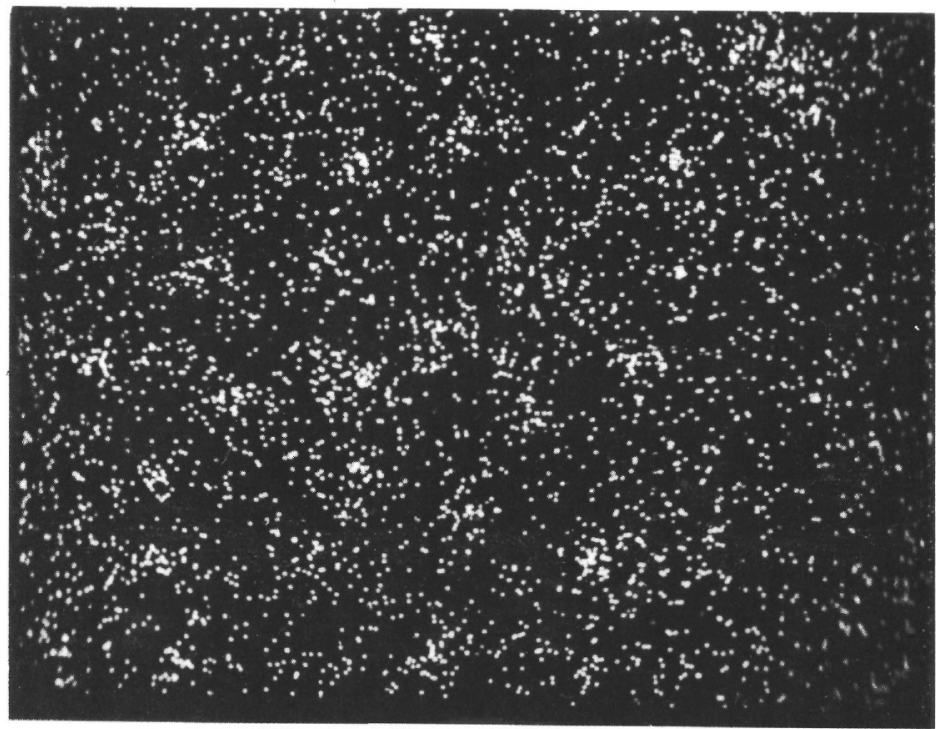

Figure 7. (a) Plane light photomicrograph of sulfide spherules (dark spots) lining vesicle walls, enclosed entirely in glass. The entire vesicle is below the upper surface of the thin section. (b) Beam scanning X-ray intensity display of S over a different vesicle. Areas of high spot density are the large spherules. The higher spot density between the large spherules within the vesicle than of the regions beyond indicate that the small spherules are also sulfides. (c) Beam scanning X-ray intensity displays of Cu and (d) of Ni in the vesicle shown in $7 b$. The X-ray images were produced at $20 \mathrm{kv}$ and 20 namps sample current and are of a $60 X 46 \mu \mathrm{m}$ area. 
cussions during its preparation. Richard Gaarden assisted in the scanning electron microscopy.

\section{REFERENCES}

Anderson, A.T., 1974. Chlorine, sulfur, and water in magmas and oceans: Geol. Soc. Am. Bull., v. 85, p. 1485-1492.

Bottinga, Y., Kudo, A.M., and Weill, D.F., 1966. Some observations on oscillatory zoning and crystallization of magmatic plagioclase: Am. Min., v. 51, p. 792-806.

Bryan, W.B., 1972. Morphology of quench crystals in submarine basalts: J. Geophys. Res., v. 77, p. 5812-5819.

Clanton, U.S., McKay, D.S., Laughton, R.B., and Ladle, G.H., 1974. Vapor-phase crystallization of iron in lunar breccias: Lunar Sci. Conf. Proc. 5th, Geochim. Cosmochim. Acta, p. 621-626.

Craig, J.R. and Kullerud, G., 1969. Phase relations in the $\mathrm{Cu}-$ Fe-Ni-S system and their application to magmatic ore deposits: Magmatic ore deposits, A symp., Econ. Geol. Mono. 4, p. 344-358.

Desborough, G.A., Anderson, A.T., and Wright, T.L., 1968. Mineralogy of sulfides from certain Hawaiian basalts: Econ. Geol., v. 63, p. 636-644.

Haughton, D.R., Roeder, P.L., and Skinner, B.J., 1974. Solubility of sulfur in mafic magmas: Econ. Geol., v. 69, p. $451-467$.

Katsura, T. and Nagashima, S., 1974. Solubility of sulfur in some magmas at 1 atmosphere: Geochim. Cosmochim. Acta, v. 38 , p. $517-531$.

Kullerud, G., Yund, R.A., and Moh, G.H., 1969. Phase relations in the $\mathrm{Cu}-\mathrm{Fe}-\mathrm{S}, \mathrm{Cu}-\mathrm{Ni}-\mathrm{S}$, and $\mathrm{Fe}-\mathrm{Ni}-\mathrm{S}$ systems: Magmatic ore deposits, a symp., Econ. Geol. Mono. 4, p. 323-343.
Liebhafsky, H.A., Pfeiffer, H.G., Winslow, E.H., and Zemany, P.D., 1960. X-ray absorption and emission in analytical chemistry: New York (John Wiley \& Sons).

Mathez, E.A., 1973. Refinement of the Kudo-Weill plagioclase thermometer and its application to basaltic rocks: Contrib. Mineral. Petrol., v. 41, p. 61-72.

Moore, J.G. and Calk, L., 1971. Sulfide spherules in vesicles of dredged pillow basalt: Am. Min., v. 56, p. 476-488.

Moore, J.G. and Fabbi, B.F., 1971. An estimate of the juvenile sulfur content of basalt: Contrib. Mineral. Petrol., v. 33, p. 118-127.

Moore, J.G. and Schilling, J.G., 1973. Vesicles, water, and sulfur in Reykjanes Ridge basalts: Contrib. Mineral. Petrol., v. 41, p. $105-118$.

Naughton, J.J., Lewis, V.A., Hammond, D., and Nishimoto, D., 1974. The chemistry of sublimates collected directly from lava fountains at Kilauea Volcano, Hawaii: Geochim. Cosmochim. Acta, v. 38, p. 1674-1690.

Rucklidge, J.C. and Gasparrini, E. L., 1969. EMPADR VIIElectron microprobe analytical data reduction program-version 7: Dept. Geol., Univ. of Toronto.

Skinner, B.J. and Peck, D.L., 1969. An immiscible sulfide melt from Hawaii: Magmatic ore deposits, A symp., Econ. Geol. Mono. 4, p. 310-322.

Yeats, R.S., Forbes, W.C., Scheidegger, K.F., Heath, G.R., and Van Andel, T.J., 1973. Core from Cretaceous basalt, Central Equatorial Pacific, Leg 16, Deep Sea Drilling Project: Geol. Soc. Am. Bull., v. 84, p. 871-882.

Yund, R.A. and Kullerud, G., 1966. Thermal stability of assemblages in the Cu-Fe-S system: J. Petrol., v. 7, p. 454488. 